\title{
ATMP derived Cobalt-metaphosphate Complex as Highly Active Catalyst for Oxygen Reduction Reaction
}

\author{
Lian-Hua Xu', Sheng-Li Zhang ${ }^{\mathrm{a}, *}$, Shi-Ying Guo ${ }^{\mathrm{a}}$, Xue-Ji Zhang ${ }^{\mathrm{a}}$, Serge Cosnier ${ }^{\mathrm{b}}$, \\ Robert S. Marks ${ }^{c}$, Wen-Ju Wang ${ }^{\mathrm{a}, *}$, Hai-Bo Zeng ${ }^{\mathrm{a}}$, Dan Shan ${ }^{\mathrm{a}, *}$ \\ ${ }^{a}$ MIIT Key Laboratory of Advanced Display Materials and Devices, School of \\ Environmental and Biological Engineering, Nanjing University of Science and \\ Technology, Nanjing 210094, China \\ ${ }^{b}$ University of Grenoble Alpes-CNRS, DCM UMR 5250, F-38000 Grenoble, France \\ ${ }^{c}$ Department of Biotechnology Engineering, Ben-Gurion University of the Negev, \\ Beer-Sheva, Israel.
}

*Corresponding author:

Email: danshan@njust.edu.cn (D. Shan) zhangslvip@njust.edu.cn (S.L. Zhang)
wangwenju1982@gmail.com (W.J.Wang)

Fax: 0086-25-84303107 


\section{ABSTRACT:}

Rational design and facile synthesis of highly active electrocatalysts with low cost for oxygen reduction reaction (ORR) are always of great challenge. Specifically, development of a new type of energy-saving materials with convenient method is regarded as the current bottleneck. Herein, an innovative strategy based on amino trimethylene phosphonic acid (ATMP) as chelating agent for cobalt-metaphosphate coordination polymer is reported to one-pot synthesis of a novel precursor in methanol for ORR electrocatalyst. Carbonization of the precursor at $900{ }^{\circ} \mathrm{C}$ at $\mathrm{N}_{2}$ atmosphere results in the feasible formation of cobalt metaphosphate based composite $\left(\mathrm{Co}\left(\mathrm{PO}_{3}\right)_{2} / \mathrm{NC}\right)$. A further step in the thermal cleavage at $650{ }^{\circ} \mathrm{C}$ at air for $4 \mathrm{~h}$, $\mathrm{Co}\left(\mathrm{PO}_{3}\right)_{2} / \mathrm{NC}$ can be finally transformed into inorganic $\mathrm{Co}\left(\mathrm{PO}_{3}\right)_{2}$. Advanced spectroscopic techniques and density function theory (DFT) calculations are applied to confirm the main catalytically active center and the physical properties of $\mathrm{Co}\left(\mathrm{PO}_{3}\right)_{2} / \mathrm{NC}$. This obtained $\mathrm{Co}\left(\mathrm{PO}_{3}\right)_{2} / \mathrm{NC}$ nanocomposite exhibits superior electrocatalysis to $\mathrm{Co}\left(\mathrm{PO}_{3}\right)_{2}$ with an enhanced onset potential (0.906 V vs. RHE) and diffusion limiting current $\left(5.062 \mathrm{~mA} \mathrm{~cm} \mathrm{~cm}^{-2}\right)$, which are roughly close to those of commercial $20 \% \mathrm{Pt} / \mathrm{C}\left(0.916 \mathrm{~V}, 5.200 \mathrm{~mA} \mathrm{~cm}^{-2}\right)$.

KEYWORDS: Amino trimethylene phosphonic acid (ATMP), Oxygen reduction reaction (ORR), Electrocatalysis, Cobalt-metaphosphate 


\section{INTRODUCTION}

Fuel cells capable of directly converting chemical energy into electrical energy has attracted great attention due to their higher power generation efficiencies, higher energy conversion efficiencies, eco-friendly and longer lifespan [1]. Nevertheless, the oxygen reduction reaction (ORR) is a sluggish step at the cathode of fuel cells, which limits the efficiency of the entire fuel cells [2]. Therefore, the development of cost-effective and efficient electrode materials for ORR are key priorities. With more and more efficient catalysts were exploited, the following critical issues still need to be resolved: (1) Finding a highly efficient chemical synthetic method to develop ORR alternative catalysts that are both high active, abundant, cost-effective and obtained feasibly. (2) Tailing a new catalytic material and mastering chemical synthetic mechanism of the catalysts based on the theory of electron transfer.

Cobalt oxide materials are promising alternatives to replace noble metal oxides for ORR [3-5]. For rationally designing electrocatalysts, coordination environment as well as the related electronic structure of the Co oxides materials should be considered to ensure a rapid procession of the reactions [6]. Transition metal metaphosphates/phosphates provide positive contributions for structural stability and can stabilize the intermediate state of the transition metal ions thus initiated wide-ranging interests [7]. Moreover, theoretical studies and experiments also indicate that the phosphate/metaphosphate group make good contributions in proton transfer, which is of great significance for catalysis. [8,9] Many methods have been developed to synthesize cobalt phosphate/metaphosphate nanostructures, such as hydrothermal 
route [10-12], thermolytic molecular precursor (TMP) method [13], sol-gel process [14], freeze-drying method [15] and combustion assisted argon-annealed route [16]. Although these cobalt phosphates/metaphosphates exhibit state-of-the-art performance for ORR [17], oxygen evolution reaction (OER) [18, 19], and renewable energy technologies (e.g. as cathode for SIBs) [20], the cost, durability and complexity of synthesis limit their sustainable application in a commercial scale [22]. Thus, seeking out an environmentally friendly and effectively synthetic path for cobalt phosphate/metaphosphate nanocomposites is a vital thing.

Amino trimethylene phosphonic acid (ATMP) is a strong complexing agent for divalent cations with the morphology of tripodal tetradentate formed by combining a central atom ' $\mathrm{N}$ ' with three ligands 'metaphosphate group'. The good chemical stability (melting point: $200{ }^{\circ} \mathrm{C}$, boiling point: $746.2{ }^{\circ} \mathrm{C}$ ), good chelation, lattice distortion as well as the cost-effective of ATMP has successfully caught our attention. In the three phosphonic groups in ATMP, the phosphorus atom forms a $\sigma$ bond with oxygen atom in form of $\mathrm{sp}^{3}$ orbital, $\mathrm{p}-\mathrm{d} \pi$ bond which is perpendicular to the $\mathrm{P}-\mathrm{O} \sigma$ bond formed between $3 \mathrm{~d}^{0} \mathrm{xz}$ and $2 \mathrm{pz}$ as well as $3 \mathrm{~d}^{0} \mathrm{xy}$ and $2 \mathrm{py}$ [22]. During the reaction, the oxygen atoms on the phosphonic group bond with Co (II) $\left(3 \mathrm{~d}^{7}\right)$ with three unpaired electron pairs to form a high spin complex, the $\sigma$ and $\pi$ orbitals of the ligand all participate in the molecular orbital of the combined complex. Thus, as depicted in Scheme 1, we firstly synthesize a novel metal organophosphate copolymer which can serve as an alternative precursor using ATMP as a chelating agent and then calcinated it to form a carbon based highly active catalyst. The main catalytically 
active center and the physical properties of cobalt metaphosphate based composite $\left(\mathrm{Co}\left(\mathrm{PO}_{3}\right)_{2} / \mathrm{NC}\right)$ have been confirmed. Meanwhile, comparative analysis of cobalt oxide $(\mathrm{CoO})$ and our synthesized $\mathrm{Co}\left(\mathrm{PO}_{3}\right)_{2} / \mathrm{NC}$ reveals the potential structural features for efficient ORR. This study provides valuable insight into the design and synthesis of efficient ORR catalysts.

[Scheme 1]

\section{Experimental section}

\subsection{Chemicals and materials}

Cobalt (II) nitrate hexahydrate $\left(\mathrm{Co}\left(\mathrm{NO}_{3}\right)_{2} \cdot 6 \mathrm{H}_{2} \mathrm{O}, \mathrm{AR}, 99 \%\right)$ and methanol $\left(\mathrm{CH}_{3} \mathrm{OH}\right.$, AR, $99 \%$ ) were purchased from Aladdin (China). The amino trimethylene phosphonic acid (ATMP, 50 wt. \%) was bought from Shanghai Meryer Chemical Technology Co. Ltd (China). Cobalt (II) oxide was obtained from Energy Chemical (China). A commercially available 20 wt. \% platinum-loaded carbon (Pt/C) loaded on carbon black (Johnson Matthey) was used as received. All other chemicals were of analytical grade and used without further purification. Distilled water was used throughout the experiment.

\subsection{Preparation of $\mathrm{Co}\left(\mathrm{PO}_{3}\right)_{2} / \mathrm{NC}, \mathrm{Co}\left(\mathrm{PO}_{3}\right)_{2}$ and $\mathrm{NC}$}

The $\mathrm{Co}\left(\mathrm{PO}_{3}\right)_{2} / \mathrm{NC}$ complex was prepared by a simple coordination reaction followed by calcination. In a typical preparation, $0.1 \mathrm{~mol} / \mathrm{L} \mathrm{Co}\left(\mathrm{NO}_{3}\right)_{2} \cdot 6 \mathrm{H}_{2} \mathrm{O}$ methanol solution was prepared. Subsequently, 2 mL ATMP (50 wt. \%) was added dropwise 
into $20 \mathrm{~mL}$ above solution and churned for 30 mins. The $\mathrm{pH}$ of the mixture is 4.54 . Superfine pink powder formed during the process of mixing. Thus, the cobalt-metaphosphate coordination polymer was obtained and used as precursor for annealing treatment. The obtained sample was further heated from room temperature to $900{ }^{\circ} \mathrm{C}$ under the protection of $\mathrm{N}_{2}$ flow with a heating rate of $5{ }^{\circ} \mathrm{C} \min ^{-1}$ and then held for $2 \mathrm{~h}$ at $900{ }^{\circ} \mathrm{C}$. After it cooled down to room temperature, the black product denoted as $\mathrm{Co}\left(\mathrm{PO}_{3}\right)_{2} / \mathrm{NC}$ was ground and collected for detection and characterization. For comparison, $\mathrm{Co}\left(\mathrm{PO}_{3}\right)_{2}$ was obtained by reheating the $\mathrm{Co}\left(\mathrm{PO}_{3}\right)_{2} / \mathrm{NC}$ at $650{ }^{\circ} \mathrm{C}$ for $4 \mathrm{~h}$ in air to oxidize and remove the carbon and nitrogen "cumbersome". NC were obtained by directly heating the ATMP at $900{ }^{\circ} \mathrm{C}$ for $2 \mathrm{~h}$.

\subsection{Materials characterization}

The ultraviolet absorption spectra were measured by UV-vis spectrophotometry (UV-3600, Shimadzu) and solid UV-vis spectrophotometry (Evolution 220). A TENSOR Model 27 FT-IR spectrometer was used for FT-IR spectra test. Thermal gravimetric and differential thermal analyses (TG-DTA) analysis was investigated on Synchro Thermal Analyzer (STA 449 F1 Jupiter. NETZSCH). The X-ray diffraction (XRD) patterns were collected on X-ray diffractometer (Bruker D8) at $40 \mathrm{kV}$ and 40 mA. With $532 \mathrm{~nm}$ solid laser as an excitation source, an iHR550 Raman microscope (HORIBA scientific) was used for Raman spectra test. The detailed morphology and size of all the catalysts were analyzed by transmission electron microscope (TEM, FEI Tecnai 20 electron microscope) and high-resolution transmission electron microscope (HRTEM, jeol jem2100f) and the element mapping images were carried 
out on Quanta 250F and FEI. The surface functional properties of all the catalysts were investigated by K-Alpha X-ray photoelectron spectroscopy (XPS, Thermo ESCALAB 250XI). The binding energies were calibrated using the $\mathrm{C} 1 \mathrm{~s}$ peak at 284.6 $\mathrm{eV}$.

\subsection{Electrochemical measurements}

All electrochemical studies were performed with a conventional three-electrode cell using a graphite rod as counter electrode, a saturated calomel $\mathrm{Hg} / \mathrm{Hg}_{2} \mathrm{Cl}_{2}$ electrode as reference electrode. Cyclic voltammetry $(\mathrm{CV})$ and rotating disk electrode (RDE, $0.196 \mathrm{~cm}^{2}$, Metrohm) were recorded on CHI660D electrochemical workstation $(\mathrm{CH}$ Instrument). Linear sweep voltammetry (LSV) experiments were executed at $10 \mathrm{mV}$ $\mathrm{s}^{-1}$ under rotating speeds varying from 400 to $2025 \mathrm{rpm}$. During electrochemical measurements a flow of $\mathrm{N}_{2}$ or $\mathrm{O}_{2}$ was maintained over the electrolyte $\left(0.1 \mathrm{~mol} \mathrm{~L}^{-1}\right.$ $\mathrm{KOH}$ ) for continuous $\mathrm{N}_{2}$ or $\mathrm{O}_{2}$ saturation. All catalysts were fabricated follow steps: Firstly, The catalyst ink $\left(10 \mathrm{mg} \mathrm{mL}^{-1}\right)$ of $\mathrm{Co}\left(\mathrm{PO}_{3}\right)_{2} / \mathrm{NC}, \mathrm{Co}\left(\mathrm{PO}_{3}\right)_{2}, \mathrm{CoO}, \mathrm{NC}$ and $\mathrm{Pt} / \mathrm{C}$ were prepared by dispersing the catalyst powders in deionized water and ultrasonic dispersion for 5 minutes. Secondly, spreading $10 \mu \mathrm{L}$ of the catalyst ink onto pretreated RDE and dried at room temperature. Finally, $5 \mu \mathrm{L}$ of Nafion/ethanol solution (5 wt.\%) was dropped on the surface of above-modified electrode and dried in air. Thus, the catalysts modified RDE were fabricated. Herein, all the potentials were converted to a reversible hydrogen electrode (RHE), $\mathrm{E}(\mathrm{RHE})=\mathrm{E}\left(\mathrm{Hg} / \mathrm{Hg}_{2} \mathrm{Cl}_{2}\right)$ $+1.008 \mathrm{~V}$. 
The RRDE test of $\mathrm{Co}\left(\mathrm{PO}_{3}\right)_{2} / \mathrm{NC}$ was conducted to verify and test the electron transfer number (n) and $\mathrm{H}_{2} \mathrm{O}_{2}$ production yield. the results were calculated according to the eq (1) and (2):

$$
\begin{aligned}
& n=\frac{4 I_{D}}{I_{D}+\left(\frac{I_{R}}{N}\right)} \\
& H_{2} O_{2} \%=100 \times \frac{4-n}{2}
\end{aligned}
$$

where $I_{D}$ and $I_{R}$ reference the desk current and ring current, respectively. where $n$ is the electron transfer number, $\mathrm{H}_{2} \mathrm{O}_{2} \%$ is the production yield during the ORR process, and $\mathrm{N}$ is the collection efficiency ( 0.35 in this study, the specific experiment is shown in Figure S1).

\subsection{Calculation Method}

All density function theory (DFT) calculations were performed based on the projector-augmented-wave method as implemented in the Vienna ab initio simulation package (VASP) [23, 24]. The Blöchl's all-electron-like projector augmented plane wave (PAW) method was used to describe the interactions between ion cores and valence electrons [25]. The electronic exchange-correlation potential was treated within the functional of Perdew-Bulrke-Ernzerhof (PBE) function for generalized gradient approximation (GGA). The plane-wave cutoff was set to $300 \mathrm{eV}$ and the convergence threshold was set as $1 \times 10^{-4} \mathrm{eV}$ in energy and $0.01 \mathrm{eV}^{-1}$ in force. The Monkhorst-Pack special $\mathrm{k}$ point was set with $3 \times 4 \times 4$ grid meshes for structure optimization and $7 \times 9 \times 9$ grid meshes for electronic property calculation. The optimized lattice constants for $\mathrm{Co}\left(\mathrm{PO}_{3}\right)_{2}$ are $\mathrm{a}=11.04 \AA, \mathrm{b}=8.09 \AA$, and $\mathrm{c}=9.56 \AA$.

A slab with $\mathrm{Co}\left(\mathrm{PO}_{3}\right)_{2}$ and $\mathrm{Co}\left(\mathrm{PO}_{3}\right)_{2} / \mathrm{NC}$ surfaces was constructed to simulate the 
reaction condition of $\mathrm{Co}\left(\mathrm{PO}_{3}\right)_{2}$ during ORR process, respectively. The supercell used for the $\mathrm{N}$-doped carbon sheet consists of 127 carbon atoms with a single doped nitrogen atom at the center. The isolated $\mathrm{Co}\left(\mathrm{PO}_{3}\right)_{2}$ nanoparticle $\left(\mathrm{Co}_{4} \mathrm{P}_{8} \mathrm{O}_{24}\right)$ was optimized in a $30.0 \AA$ cubic supercell in which the Brillouin zone integration was carried out for the $\Gamma$-point only. The ORR reaction pathways can be expressed as the following four steps:

$\mathrm{O}_{2}+*+\left(H^{+}+e^{-}\right) \rightarrow \mathrm{OOH}^{*}$

$\mathrm{OOH}^{*}+\left(\mathrm{H}^{+}+e^{-}\right) \rightarrow \mathrm{O}^{*}+\mathrm{H}_{2} \mathrm{O}$

$O^{*}+\left(H^{+}+e^{-}\right) \rightarrow O H^{*}$

$\mathrm{OH}^{*}+\left(H^{+}+e^{-}\right) \rightarrow \mathrm{H}_{2} \mathrm{O}+*$

The computational hydrogen electrode model proposed by Nørskov and co-workers was used to express the thermochemistry of the sub-reactions at any given $\mathrm{pH}$ and applied potential $U$. The free energies were calculated from total energies using Eq. (5). where $\mathrm{i}=1,2,3,4$ corresponds to each step in Eq. (3-6). $\Delta E$ is the reaction energy, $\triangle Z P E$ is the change of zero-point energy, $T(298.15 \mathrm{~K})$ is temperature, $\Delta S$ is the difference in entropy. The zero-point energies were calculated from the vibration frequencies. The entropies were taken from standard tables for gas-phase molecules [26] Gas phase $\mathrm{H}_{2} \mathrm{O}$ at 0.035 bar was used as the reference state, because, at this pressure, gas phase $\mathrm{H}_{2} \mathrm{O}$ is in equilibrium with liquid water at $300 \mathrm{~K}$. GORR and $\eta$ ORR were then given by Eq. (7-9).

$$
\begin{aligned}
& \Delta G_{i}=\Delta E_{i}+\Delta Z P R_{i}-T \Delta S_{i} \\
& G^{O R R}=\max \left[\Delta G_{1}, \Delta G_{2}, \Delta G_{3}, \Delta G_{4}\right]
\end{aligned}
$$




$$
\eta^{O R R}=\left(G^{O R R} / e\right)+1.23 V
$$

\section{Result and discussion}

Initially, a series of advanced spectroscopic techniques were used to confirm the successful coordination occurred between ATMP and Co(II). The UV-vis absorption measurements were performed in the range of $300-800 \mathrm{~nm}$ at room temperature is illustrated in Figure 1A. Herein, the precursor of $\mathrm{Co}\left(\mathrm{PO}_{3}\right)_{2} / \mathrm{NC}$ was fabricated by mixing $\mathrm{Co}$ (II) and ATMP in $\mathrm{H}_{2} \mathrm{O} / \mathrm{CH}_{3} \mathrm{OH}\left(V_{\mathrm{H}_{2} \mathrm{O}}: V_{C_{3} O H}=1: 10\right)$ for $0.5 \mathrm{~h}$. The absorption of ATMP and Co (II) can be found at $685 \mathrm{~nm}$ and $542 \mathrm{~nm}$ respectively. Surprisingly, a distinct blue-shift was found in Co (II)-ATMP complex, showing a new peak at $510 \mathrm{~cm}^{-1}$. An implication of this phenomenon is the possibility that Co ions have a strong combination with ATMP.

Figure 1B shows the FI-IR spectra of ATMP and the precursor of $\mathrm{Co}\left(\mathrm{PO}_{3}\right)_{2} / \mathrm{NC}$. The band at $933 \mathrm{~cm}^{-1}$ and $1064 \mathrm{~cm}^{-1}$ are attributed to the stretching vibration of $\mathrm{P}-\mathrm{OH}$ groups in organic phosphonic acid group in ATMP [27]. The corresponding two absorption peaks in the precursor simultaneously occurred red-shift which located at $920 \mathrm{~cm}^{-1}$ and $1004 \mathrm{~cm}^{-1}$ respectively. A possible explanation for the shift might be that the two hydroxyl groups adjacent to the phosphorus atom in the ligands in ATMP dissociate the $\mathrm{H}^{+}$and then coordinate with the Co (II). Additionally, the band at 1204 $\mathrm{cm}^{-1}$ corresponds to the stretching vibration of $\mathrm{P}=\mathrm{O}$ groups in ATMP [28]. The position of this peak also shifted in the precursor which located in $1155 \mathrm{~cm}^{-1}$. This discrepancy could be attributed to that the oxygen adjacent to phosphorus contains 
two pairs of lone electron pairs are prone to chelate with Co (II).

The solid UV-vis absorption patterns of ATMP and the precursor of $\mathrm{Co}\left(\mathrm{PO}_{3}\right)_{2} / \mathrm{NC}$ are illustrated in Figure 1C. What is surprising is that a significant difference appeared at $533 \mathrm{~nm}$ in the precursor, corresponding to O-donner octahedral $\mathrm{Co}^{2+}$ complexes [4T1g $\rightarrow 4 \mathrm{~T} 1 \mathrm{~g}(\mathrm{P})$ transition] [28]. This accords with our earlier observations, which showed that Co ions have successfully combined with oxygen which adjacent to phosphorus in ATMP through chelation.

Thermogravimetric analyses open interesting ways for the determination the thermal degradation behaviors of the metal complexes as well as structural elucidation. TG-DTA experiments were performed on the precursor under an $\mathrm{N}_{2}$ atmosphere with a heating rate of $10{ }^{\circ} \mathrm{C} \min ^{-1}$. It can be seen from Figure 1D that the weight drops $\sim 13 \%$ below $325{ }^{\circ} \mathrm{C}$ is ascribed to the evaporation of solvent (the mixed solution of methanol and water) and the self-polymerization under melting state of ATMP, associated with an intense exothermic peak at $325{ }^{\circ} \mathrm{C}$ in DTA curve [29]. The weight drops $\sim 6 \%$ from $325{ }^{\circ} \mathrm{C}$ to $445{ }^{\circ} \mathrm{C}$ is attributed to the forming of 2-propane amine, cobalt-trimethyl phosphine and cobalt-trimethyl phosphine oxide [22]. Which deserving additional attention is that the reason for the weight loss (about 26\%) from $445{ }^{\circ} \mathrm{C}$ to $626{ }^{\circ} \mathrm{C}$ stemmed from the appearance of trimethylamine, cobalt-trimethyl phosphine oxide, tetramethylpyrrole, 4-dimethylaminophenol and multiple substituted benzene compounds [22]. The process accompanied by small amount of heat release. With temperature increases, the weight drops $\sim 9 \%$ from $626{ }^{\circ} \mathrm{C}$ to $900{ }^{\circ} \mathrm{C}$ reveal the gasification of the excessive ATMP and other organic compounds. Simultaneously, the 
free nitrogen atoms are far more likely to form pyrrole/pyridine rings with carbon which facilitates the electron transmission process. As for this N-doped carbon, the electric neutrality of carbon atoms could be destroyed due to the insertion of $\mathrm{N}$ atoms into the graphitic lattice [30]. The enlarged spin density and unevenly distributed charge density of carbon atoms could facilitate the adsorption of oxygen and subsequent reduction reaction on carbon [30, 31].

[Figure 1]

The composition and crystalline nature of the obtained pyrolysis products were identified by powder X-ray diffraction (XRD). As illustrated in Figure 2A, 10 obvious diffraction peaks can be observed in $\mathrm{Co}\left(\mathrm{PO}_{3}\right)_{2} / \mathrm{NC}$ and $\mathrm{Co}\left(\mathrm{PO}_{3}\right)_{2}$ at the $2 \theta$ ranging from $10^{\circ}$ to $60^{\circ}$, which can be indexed to (011), (-112), (211), (121), (310), (-222), (013), (400), (222), and (-233) planes of $\mathrm{Co}\left(\mathrm{PO}_{3}\right)_{2}$ with a monoclinic phase structure (PDF No. 27-1120). The diffraction peaks of $\mathrm{CoO}$ are indexed with a monoclinic phase structure (PDF No. 43-1004) (Figure S2). The Raman spectroscopy is shown in Figure $2 \mathrm{~B}$, the sharp peak at $671 \mathrm{~cm}^{-1}$ corresponds to the symmetric stretching vibration of $\mathrm{Q}^{2}$ bridge oxygen and the small peak located at around $1139 \mathrm{~cm}^{-1}$ is attributed to the symmetric stretching vibration of $\mathrm{Q}^{2}$ bridge oxygen $\left(\mathrm{PO}_{2}\right)$, implying the structure of metaphosphate in the catalyst. The clear D band at $1339 \mathrm{~cm}^{-1}$ (defective graphitic structures) and $\mathrm{G}$ band $\left(\mathrm{E}_{2 \mathrm{~g}}\right.$-mode from the $\mathrm{sp}^{2}$ carbon domain) at $1558 \mathrm{~cm}^{-1}$ peaks are attributed to the carbon material $[31,32]$. As shown in EDS 
mapping (Figure 2C), the existence of $\mathrm{N}$ can be demonstrated, and the homogenous distribution of $\mathrm{C}, \mathrm{O}, \mathrm{Co}, \mathrm{P}$ and $\mathrm{N}$ can also be exhibited. Figure $\mathrm{S} 3$ shows the FI-IR spectra of $\mathrm{Co}\left(\mathrm{PO}_{3}\right)_{2}$ and $\mathrm{Co}\left(\mathrm{PO}_{3}\right)_{2} / \mathrm{NC}$. The weak absorption peaks at $1200 \mathrm{~cm}^{-1}$ is ascribed to the stretching vibration of $\mathrm{N}-\mathrm{C}$ bond [33], showing the successful doping of nitrogen in $\mathrm{Co}\left(\mathrm{PO}_{3}\right)_{2} / \mathrm{NC}$ carbon materials. Since the $\mathrm{N}$ atom is inserted into the graphite lattice, the electric neutrality and the charge density of carbon atoms could be destroyed [34]. An increase in the spin density of carbon atoms could promote the adsorption of oxygen and subsequent reduction reaction on carbon [30, 35].

The morphology of all the synthesized catalysts were examined by SEM and TEM images. Figure S4A, S4B and S4C show the SEM images of NC, $\mathrm{CoO}$ and $\mathrm{Co}\left(\mathrm{PO}_{3}\right)_{2}$. It can be observed that the morphology of the NC exhibits a sheet-like structure, the $\mathrm{CoO}$ and $\mathrm{Co}\left(\mathrm{PO}_{3}\right)_{2}$ show a granular morphology. The surface of the $\mathrm{CoO}$ particles is relatively smooth, while the surface of the $\mathrm{Co}\left(\mathrm{PO}_{3}\right)_{2}$ particles is relatively rough, corresponding to the results of TEM (Figure S4D, S4E and S4F). In addition, there are some agglomerations of $\mathrm{Co}\left(\mathrm{PO}_{3}\right)_{2}$. Figure $2 \mathrm{D}$ and $2 \mathrm{E}$ show many ultrathin nanosheets are randomly compact and cross erectly together. It is observed that the single nanosheet has $20-50 \mathrm{~nm}$ in thickness. The lengths of the single erect plate are not uniform and they are in the range of $0.5-2 \mu \mathrm{m}$. Meanwhile, the rough surface on the carbon nanoplate in favor of exposing abundant marginal defective sites, which are beneficial for enhancing electrochemical performance [33]. The representative TEM images (Figure $2 \mathrm{~F}$ ) of $\mathrm{Co}\left(\mathrm{PO}_{3}\right)_{2} / \mathrm{NC}$ reveal that there are many $\mathrm{Co}\left(\mathrm{PO}_{3}\right)_{2} \mathrm{NPs}$ (about $\sim 10 \mathrm{~nm}$ in diameter) are encapsulated by $\mathrm{N}$-doped carbon layers, which act as 
bridges connect the $\mathrm{Co}\left(\mathrm{PO}_{3}\right)_{2} \mathrm{NPs}$. The tight connection of carbon and $\mathrm{Co}\left(\mathrm{PO}_{3}\right)_{2} \mathrm{NPs}$ synergistically enhance the overall electron transfer capability [10]. From the HRTEM images (Figure $2 \mathrm{G}$ ) of $\mathrm{Co}\left(\mathrm{PO}_{3}\right)_{2} / \mathrm{NC}$ nanocomposite, the lattice fringes are clearly visible in the bulk portion the particle, indicating single crystallinity of the particles. The $1.47 \AA$ spacing corresponds to the (121) plane of monoclinic $\mathrm{Co}\left(\mathrm{PO}_{3}\right)_{2}$.

[Figure 2]

XPS was performed to investigate the bonding configuration and chemical state in $\mathrm{Co}\left(\mathrm{PO}_{3}\right)_{2} / \mathrm{NC}$. The full XPS survey spectra of $\mathrm{NC}$ (Figure $\left.\mathrm{S} 5 \mathrm{~A}\right), \mathrm{Co}\left(\mathrm{PO}_{3}\right)_{2}$ and $\mathrm{Co}\left(\mathrm{PO}_{3}\right)_{2} / \mathrm{NC}$ (Figure 3A) both show three main peaks of $\mathrm{C} 1 \mathrm{~s}$ (actually a trace amount of residual carbon existed in $\mathrm{Co}\left(\mathrm{PO}_{3}\right)_{2}, \mathrm{O}$ 1s and $\mathrm{P} 2 \mathrm{p}$ at $284.15 \mathrm{eV}, 533.0 \mathrm{eV}$ and $133.9 \mathrm{eV}$, respectively. In addition, the content of nitrogen in $\mathrm{Co}\left(\mathrm{PO}_{3}\right)_{2}$ is close to zero, and no peak treatment is done. We first focus on the fine spectrum of $\mathrm{Co}\left(\mathrm{PO}_{3}\right)_{2} / \mathrm{NC}$, the XPS survey spectrum of $\mathrm{Co}\left(\mathrm{PO}_{3}\right)_{2} / \mathrm{NC}$ appeared obvious $\mathrm{N} 1$ s peak, confirming successful $\mathrm{N}$ doped. As shown in Table S1, quantitative XPS analysis shows that the concentration of nitrogen is 2.02 for $\mathrm{Co}\left(\mathrm{PO}_{3}\right)_{2} / \mathrm{NC}$. As shown in Figure $3 \mathrm{~B}$, the $\mathrm{N} 1 \mathrm{~s}$ XPS spectra of $\mathrm{Co}\left(\mathrm{PO}_{3}\right)_{2} / \mathrm{NC}$ was decomposed into four dominant peaks, which correspond to pyridinic $\mathrm{N}(398.57 \mathrm{eV}), \mathrm{Co}-\mathrm{N}_{\mathrm{x}}(400.21 \mathrm{eV})$, graphitic $\mathrm{N}(401.62$ $\mathrm{eV}$ ) and oxide $\mathrm{N}(404.51 \mathrm{eV})$, respectively. We are surprised to find that the nitrogen peak of $\mathrm{NC}$ (Figure S5B) is similar to that of $\mathrm{Co}\left(\mathrm{PO}_{3}\right)_{2} / \mathrm{NC}$, indicating that the main source of nitrogen in $\mathrm{Co}\left(\mathrm{PO}_{3}\right)_{2} / \mathrm{NC}$ comes from $\mathrm{NC}$. We also performed an elemental 
analysis of NC (Table S2), where the nitrogen content was $1.41 \%$. It is considered that carbon materials with $\mathrm{N}$ doping promote the charge mobility in the carbon matrix, which can accelerate the catalytic activity [32]. While for P $2 p$ fine spectrum (Figure 3C), the deconvoluted two sub-peaks located at 134.60 and $135.50 \mathrm{eV}$ are the characteristic $\mathrm{P} 2 \mathrm{p}_{1 / 2}$ and $2 \mathrm{p}_{3 / 2}$ peaks for the $\mathrm{Co}\left(\mathrm{PO}_{3}\right)_{2}$ group in the form of $\mathrm{PO}_{3}{ }^{2-}$. As for comparison, the content of $\mathrm{P} 2 \mathrm{p}_{1 / 2}$ is higher than the content of $2 \mathrm{p}_{3 / 2}$ in NC (Figure $\mathrm{S} 5 \mathrm{C})$, which is contrary to the that of $\mathrm{Co}\left(\mathrm{PO}_{3}\right)_{2} / \mathrm{NC}$, indicating that the successful chelation of $\mathrm{Co}^{2+}$ with ATMP affects the peaks of $\mathrm{P}$ in $\mathrm{Co}\left(\mathrm{PO}_{3}\right)_{2} / \mathrm{NC}$. Meanwhile, the XPS spectra of $\mathrm{Co}\left(\mathrm{PO}_{3}\right)_{2}$ nanostructures are also given. The states of $\mathrm{P}$ element in $\mathrm{Co}\left(\mathrm{PO}_{3}\right)_{2}$ sample are similar to that in $\mathrm{Co}\left(\mathrm{PO}_{3}\right)_{2} / \mathrm{NC}$ nanocomposite, but the $\mathrm{BEs}$ of $\mathrm{P}$ elements in $\mathrm{Co}\left(\mathrm{PO}_{3}\right)_{2} / \mathrm{NC}$ are obviously shifted to high-energy direction due to the presence of carbon which delicate a strong electronic coupling effect from carbon layers to 'metaphosphoric acid group', affecting the binding energy of Co consequently. As for Co $2 \mathrm{p}$ fine spectrum (Figure 3D), the $\mathrm{Co}_{2 \mathrm{p} 3 / 2}$ and $\mathrm{Co}_{2 \mathrm{p} 1 / 2}$ peaks are deconvoluted into four components after deconvolution. The peaks at 782.83 and $799.11 \mathrm{eV}$ are corresponding to the Co (II). The peaks at 786.86 and $804.03 \mathrm{eV}$ are corresponding to the $\mathrm{Co}$ (III), respectively. $\mathrm{Co}\left(\mathrm{PO}_{3}\right)_{2} / \mathrm{NC}$ has a higher proportion of Co (II) (sum to $52.20 \%$ ) than $\mathrm{Co}\left(\mathrm{PO}_{3}\right)_{2}$ (sum to $38.42 \%$ ) and a lower proportion of Co (III) (sum to $31.00 \%$ ) than $\mathrm{Co}\left(\mathrm{PO}_{3}\right)_{2}$ (sum to $38.81 \%$ ). It is well known that the vital components of cobalt-oxygen catalysts in oxygen reduction reaction is Co (II), which are beneficial to accelerate the catalytic activity [36]. 
[Figure 3]

The ORR activity of all the catalysts were assessed using the RDE technique, with $\mathrm{NC}, \mathrm{CoO}, \mathrm{Co}\left(\mathrm{PO}_{3}\right)_{2}, \mathrm{Co}\left(\mathrm{PO}_{3}\right)_{2} / \mathrm{NC}$ and $\mathrm{Pt} / \mathrm{C}$ being studied under the same experimental conditions for comparison. Figure 4A and Figure S6 present the CVs of $\mathrm{NC}, \mathrm{CoO}, \mathrm{Co}\left(\mathrm{PO}_{3}\right)_{2} \mathrm{Co}\left(\mathrm{PO}_{3}\right)_{2} / \mathrm{NC}$ and $\mathrm{Pt} / \mathrm{C}$ in $\mathrm{N}_{2}$ and $\mathrm{O}_{2}$ saturated $0.1 \mathrm{M} \mathrm{KOH}$ at scan rate of $10 \mathrm{mV} \mathrm{s}^{-1}$. For $\mathrm{Co}\left(\mathrm{PO}_{3}\right)_{2} / \mathrm{NC}$ nanocomposite, the $\mathrm{Ep}$ of $\mathrm{Co}\left(\mathrm{PO}_{3}\right)_{2} / \mathrm{NC}$ (0.816 V vs. RHE) was more positive than NC (0.767 V vs. RHE), CoO (0.724 V vs. RHE) and $\mathrm{Co}\left(\mathrm{PO}_{3}\right)_{2}(0.686 \mathrm{~V}$ vs. RHE), and it was in proximity to commercial $\mathrm{Pt} / \mathrm{C}$ ( $0.858 \mathrm{~V}$ vs. RHE). It is suggested that the doping of $\mathrm{N}$ has greatly improve the electrochemical performance in this work. Interestingly, it can be found that two distinguishable oxidation peaks at around 0.902 and $1.090 \mathrm{~V}$ were found at the CV curve recorded with $\mathrm{Co}\left(\mathrm{PO}_{3}\right)_{2} / \mathrm{NC}$, which may be ascribed to the existence of Co at the lower valence state which in turn accelerates ORR. Figure 4B shows the RDE voltammograms at a rotation speed of $1600 \mathrm{rpm}$ for all samples. $\mathrm{Co}\left(\mathrm{PO}_{3}\right)_{2} / \mathrm{NC}$ exhibits the enhanced performance with a relatively positive onset potential $\left(E_{\text {onset }}=\right.$ $0.906 \mathrm{~V}$ vs. RHE), half wave potential $\left(E_{1 / 2}=0.780 \mathrm{~V}\right.$ vs. RHE) and diffusion limiting current $\left(J_{\mathrm{L}}=5.062 \mathrm{~mA} \mathrm{~cm}^{-2}\right)$ compared with $\mathrm{NC}\left(0.835 \mathrm{~V}, 0.726 \mathrm{~V}, 3.616 \mathrm{~mA} \mathrm{~cm}^{-2}\right)$, $\mathrm{CoO}\left(0.827 \mathrm{~V}, 0.662 \mathrm{~V}, 2.232 \mathrm{~mA} \mathrm{~cm}^{-2}\right), \mathrm{Co}\left(\mathrm{PO}_{3}\right)_{2}\left(0.835 \mathrm{~V}, 0.726 \mathrm{~V}, 2.670 \mathrm{~mA} \mathrm{~cm}^{-2}\right)$, and comparable to $\left.\mathrm{Pt} / \mathrm{C}(0.916 \mathrm{~V}, 0.800 \mathrm{~V}, 5.200 \mathrm{~mA} \mathrm{~cm})^{-2}\right)$. The pronounced performance of $\mathrm{Co}\left(\mathrm{PO}_{3}\right)_{2} / \mathrm{NC}$ is associated with the advantage of the intimate connection between $\mathrm{N}$ doped carbon and $\mathrm{Co}\left(\mathrm{PO}_{3}\right)_{2} \mathrm{NPs}$, which could trigger a 
synergistic effect thus accelerates electron transfer for the ORR process [37]. Moreover, in order to gain a further insight ORR kinetics of our synthesized catalysts, RDE tests at various rotations were performed (Figure S7). With increasing rotation speed from 400 to $2025 \mathrm{rpm}$, the current density increases gradually, indicating an increase of $\mathrm{O}_{2}$ diffusion on the surface of electrode. The number (n) of electrons transferred of above catalysts can be obtained from the corresponding K-L plot, the value of $\mathrm{n}$ of $\mathrm{Co}\left(\mathrm{PO}_{3}\right)_{2} / \mathrm{NC}$ is 3.92, indicating a dominated four-electron pathway in the ORR proceeded. The RRDE test of $\mathrm{Co}\left(\mathrm{PO}_{3}\right)_{2} / \mathrm{NC}$ was conducted to verify and test the electron transfer number (n) and $\mathrm{H}_{2} \mathrm{O}_{2}$ production yield. (Figure S8) We can see that, in the potential range from 0 to $1.0 \mathrm{~V}$, the $\mathrm{n}$ value of $\mathrm{Co}\left(\mathrm{PO}_{3}\right)_{2} / \mathrm{NC}$ remains between 3.7 and 4.0. This clearly reveals that the ORR on $\mathrm{Co}\left(\mathrm{PO}_{3}\right)_{2} / \mathrm{NC}$ follows an efficient one-step, four-electron pathway over the entire potential range with a low $\mathrm{H}_{2} \mathrm{O}_{2}$ production yield.

Electrochemical surface area (ECSA), reflecting the amount of catalyst in contact with the electrolyte, was obtained by measuring the $\mathrm{CV}$ curves with various scan rates with iR-corrected potentials of $0.9 \mathrm{~V}$ vs. RHE (Figure S9 and Figure S10). The double-layer capacitances of the $\mathrm{Co}\left(\mathrm{PO}_{3}\right)_{2}, \mathrm{CoO}, \mathrm{NC}$ and $\mathrm{Co}\left(\mathrm{PO}_{3}\right)_{2} / \mathrm{NC}$ catalysts are calculated to be $0.1,0.36,8.2$ and $12.6 \mathrm{~F} \mathrm{~g} \mathrm{~g}^{-1}$, respectively. After thermal cleavage at $650{ }^{\circ} \mathrm{C}$ at air for $4 \mathrm{~h}$, the carbon and nitrogen "cumbersome" drop off the surface of $\mathrm{Co}\left(\mathrm{PO}_{3}\right)_{2} / \mathrm{NC}$ and the catalyst surface becomes much smoother and thus reduces the ECSA (Figure S3C). The formation of $\mathrm{N}$-doped carbon on the surface of $\mathrm{Co}\left(\mathrm{PO}_{3}\right)_{2}$ could largely increases the electrochemical surface. 
For the sake of evaluating the practical application of our catalyst, the durability and methanol-tolerance are key parameters. As performed in Figure 4C, slight performance attenuation with higher current retention can be achieved of $\mathrm{Co}\left(\mathrm{PO}_{3}\right)_{2} / \mathrm{NC}$ with approximately $85.6 \%$ relative current persisted after the test for 400 mins, whereas the commercial Pt/C retained only $83.8 \%$ of its initial current. It indicates a longer-term stability of $\mathrm{Co}\left(\mathrm{PO}_{3}\right)_{2} / \mathrm{NC}$ over the $\mathrm{Pt} / \mathrm{C}$ in an alkaline electrolyte. As is known to all, fuel molecules (e.g., methanol) which may cause the fuel crossover effect when it passes through the membrane and poison the cathode catalyst. Herein, the methanol-tolerance of the $\mathrm{Co}\left(\mathrm{PO}_{3}\right)_{2} / \mathrm{NC}$ and $\mathrm{Pt} / \mathrm{C}$ catalysts were noted at $0.4 \mathrm{~V}$ (vs. RHE). As shown in Figure 4D, slight performance degradation $(96 \%)$ was achieved with $\mathrm{Co}\left(\mathrm{PO}_{3}\right)_{2} / \mathrm{NC}$ after the injection of $3 \mathrm{M}$ methanol into the electrolyte at $600 \mathrm{~s}$. In contrast, the commercial $\mathrm{Pt} / \mathrm{C}$ catalyst decreased more significantly. The results obviously confirm that the $\mathrm{Co}\left(\mathrm{PO}_{3}\right)_{2} / \mathrm{NC}$ possesses a high resistance to methanol crossover.

The XPS, XRD and morphology characterization after ORR of $\mathrm{Co}\left(\mathrm{PO}_{3}\right)_{2} / \mathrm{NC}$ have been conducted to support the good stability of $\mathrm{Co}\left(\mathrm{PO}_{3}\right)_{2} / \mathrm{NC}$. The composition of $\mathrm{Co}\left(\mathrm{PO}_{3}\right)_{2} / \mathrm{NC}$ was firstly identified by $\mathrm{XRD}$, as is shown in Figure S11, all diffraction peaks matched well with the $\mathrm{Co}\left(\mathrm{PO}_{3}\right)_{2}$ (PDF No. 27-1120). This indicates that the crystal structure of the catalyst is mainly composed of $\mathrm{Co}\left(\mathrm{PO}_{3}\right)_{2}$ crystal after ORR test. In addition, the surface composition after ORR reaction was observed by XPS (Figure S12). The same binding energies of N 1s (Figure S12A), P 2p (Figure S12B) and Co $2 p$ (Figure S12C) were found for the recycled sample indicating that there is no 
change in the valence state of $\mathrm{N} 1 \mathrm{~s}, \mathrm{P} 2 \mathrm{p}$ and Co $2 \mathrm{p}$.). Representative HRTEM images of the surface before and after ORR reaction are shown in Figure S13. The lattice fringes in the images of samples both before and after ORR are visible up. Such observations indicate no evidence of any phase transformation during the ORR reaction, supporting that our catalyst has good stability.

[Figure 4]

To further verify the main active site in our catalyst, one more control experiment was performed. The $\mathrm{Co}\left(\mathrm{PO}_{3}\right)_{2} / \mathrm{NC}$ catalyst was acid treated in $\mathrm{HCl}(5 \mathrm{M})$ for two days to remove the cobalt metaphosphate nanoparticles as much as possible. The final product washed three times with $\mathrm{HCl}$ and $\mathrm{DI}$ water and then dried overnight in a vacuum. From the ICP test in Table S3, the content of Co $(0.6 \mathrm{wt} \%$ Co remaining after etching) confirms that most of the cobalt metaphosphate was removed. As shown in Figure S14, the HCl-etched sample presents much inferior activity compared to the original $\mathrm{Co}\left(\mathrm{PO}_{3}\right)_{2} / \mathrm{NC}$, though XPS confirmed the presence of nitrogen (Figure S15). This result suggests that cobalt metaphosphate as a main component is indispensable for $\mathrm{Co}\left(\mathrm{PO}_{3}\right)_{2} / \mathrm{NC}$ to achieve efficient catalytic activity.

Density function theory (DFT) calculations were then performed to investigate the electronic properties of $\mathrm{Co}\left(\mathrm{PO}_{3}\right)_{2}$ and the main active site in $\mathrm{Co}\left(\mathrm{PO}_{3}\right)_{2} / \mathrm{NC}$, as shown in Figure $5 \mathrm{~A}$, the calculated electronic structures of $\mathrm{Co}\left(\mathrm{PO}_{3}\right)_{2}$ indicate its intrinsic band gap of $1.81 \mathrm{eV}$. From the atom-projected density of states, the valence band 
maximum (VBM) is composed of Co-atom and O-atom while the conduction band minimum $(\mathrm{CBM})$ is composed of $\mathrm{O}$-atom and $\mathrm{P}$-atom. The corresponding charge densities can be found in Figure 5B and 5C, clearly showing highly localized electron around $\mathrm{Co}$ for $\mathrm{VBM}$ and $\mathrm{O}$ for $\mathrm{CBM}$ and thus giving rise to a finite band gap. Improving electron transport inside the intrinsic semiconductor as electrocatalyst is of crucial importance. In this sense one can say that by decorated with N-doped graphitic carbon could effectively facilitate electron transport inside the electrocatalyst phase, enhancing the electrocatalytic performance of $\mathrm{Co}\left(\mathrm{PO}_{3}\right)_{2}$. The side view of the adsorbed $\mathrm{Co}\left(\mathrm{PO}_{3}\right)_{2}$ nanoparticle on the surface of $\mathrm{N}$-doped carbon was shown in Figure 5D. The previous theoretical studies demonstrated that the ORR activities are mainly driven by the energetics of the ORR intermediates $\left(\mathrm{OOH}^{*}, \mathrm{O}^{*}\right.$ and $\left.\mathrm{OH}^{*}\right)$ on the surface of catalysts [37]. As depicted in Figure 5E. The first reduction step is the hydrogenation of the adsorbed $\mathrm{O}_{2}$, leading to the formation of $\mathrm{OOH}$ adsorbed on the active site (Eq. 3). Then, the formed $\mathrm{OOH}$ continuously undergoes hydrogenation reaction (Eq. 4). Next, the formed atomic $\mathrm{O}$ is undergoing the reduction steps to the final $\mathrm{H}_{2} \mathrm{O}$ assisted by sequential hydrogenation reaction (Eq. 5 and Eq. 6). When this $\mathrm{H}_{2} \mathrm{O}$ molecule leaves the active sites, the catalyst recovers to its original configuration, waiting for the next catalytic cycle. Figure S16 correspond to the computational structural models of $\mathrm{CoO}, \mathrm{NC}$ and $\mathrm{Co}\left(\mathrm{PO}_{3}\right)_{2}$. Adsorption energy of different adsorption sites are shown in Table S4, it can be seen that the absolute value of the adsorption energy of the $\mathrm{Co}_{\text {site }}$ for the oxygen reduction intermediate is the largest, indicating that $\mathrm{OOH}^{*}, \mathrm{O}^{*}$ and $\mathrm{OH}^{*}$ are more likely to be adsorbed on the $\mathrm{Co}_{\text {site. }}$ The 
side view of the binding configurations of $* \mathrm{OH}$, *O, and $* \mathrm{OOH}$ on the $\mathrm{Co}\left(\mathrm{PO}_{3}\right)_{2} / \mathrm{NC}$ is shown in Figure 5E. In addition, in order to study the effect of loaded $\mathrm{Co}\left(\mathrm{PO}_{3}\right)_{2}$ on the activity of $\mathrm{N}_{\text {site, }}$, we calculated the effect of $\mathrm{Co}_{\text {site }}$ on $\mathrm{N}_{\text {site }}$ through a top-down method and denoted it as $\mathrm{Co}_{\text {site }}-\mathrm{N}_{\text {site. }}$ As shown in Figure 5F, the overpotential of $\mathrm{Co}_{\text {site }}-\mathrm{N}_{\text {site }}(\eta=0.81 \mathrm{~V})$ is larger than $\mathrm{Co}\left(\mathrm{PO}_{3}\right)_{2} / \mathrm{NC}(\eta=0.71 \mathrm{~V})$, indicating that the supported $\mathrm{Co}\left(\mathrm{PO}_{3}\right)_{2}$ can promote the activity of Nsite. Therefore, $\mathrm{Co}_{\text {site }}$ is the main active center. Moreover, the overpotential of $\mathrm{Co}\left(\mathrm{PO}_{3}\right)_{2} / \mathrm{NC}(\eta=0.71 \mathrm{~V})$ is smaller than that of $\mathrm{NC}(\eta=0.93 \mathrm{~V}), \mathrm{CoO}(\eta=0.97 \mathrm{~V})$ and $\mathrm{Co}\left(\mathrm{PO}_{3}\right)_{2}(\eta=0.79 \mathrm{~V})$, indicating that the existence of $\mathrm{NC}$ reduces the overpotential of $\mathrm{Co}\left(\mathrm{PO}_{3}\right)_{2} / \mathrm{NC}$ thus accelerate ORR. The calculated results are consistent with the experimental results. In our study, $\mathrm{Co}\left(\mathrm{PO}_{3}\right)_{2}$ groups as the main active site may be attributed to its excellent proton transfer properties, thus facilitating the ORR process. [8,9] The N-doped graphitic carbon formed in situ can further enhance the catalytic activity of the system.

In our work, the ATMP not only acted as the metaphosphate source, but also thermally decomposed into $\mathrm{N}$ doped carbon coating on $\mathrm{Co}\left(\mathrm{PO}_{3}\right)_{2} \mathrm{NPs}$ during the annealing process. We also proposed the feasible growth mechanism. After $\mathrm{Co}^{2+}$ linked to ATMP in solution, under a high temperature treatment, $\mathrm{Co}\left(\mathrm{PO}_{3}\right)_{2}$ grew to be well crystalline nanoparticles and ATMP decomposed to be $\mathrm{N}$ doped carbon, gradually. Notably, the $\mathrm{N}$ doped carbon was extruded out and coated on the surface of $\mathrm{Co}\left(\mathrm{PO}_{3}\right)_{2}$ NPs to form a network structure. The existence of $\mathrm{NC}$ has made great contribution to improving the stability of ORR. The catalytic properties of the materials in the same system as our catalytic materials are shown in Table S5. Compared with most 
materials, our proposed $\mathrm{Co}\left(\mathrm{PO}_{3}\right)_{2} / \mathrm{NC}$ own many advantages such as high limiting current density, easily available source of phosphorus, easy to synthesize and structural stability. In addition, the cost of our catalyst is very low (the price of $\mathrm{Co}\left(\mathrm{PO}_{3}\right)_{2} / \mathrm{NC}$ is about $13.8 \mathrm{RMB} / \mathrm{g}$, which is much lower than commercial $20 \mathrm{wt}$ \% $\mathrm{Pt} / \mathrm{C}$ (about $800 \mathrm{RMB} / \mathrm{g}$ ), see table S6 and S7). We really hope to develop the potential of this kind of materials through more in-depth research in future.

To further understand the influence of $\mathrm{P}$ on the length of $\mathrm{Co}-\mathrm{O}$ bond and the angle of Co-O-P bond. we examined the crystal structure of $\mathrm{CoO}$ and $\mathrm{Co}\left(\mathrm{PO}_{3}\right)_{2}$. The corresponding structural parameters are summarized in Table S8-S11. the distance of the Co-O bond $(2.0285-2.1768 \AA)$ in $\mathrm{Co}\left(\mathrm{PO}_{3}\right)_{2}$ is significantly longer than $\mathrm{CoO}$ $(1.989 \AA)$, and the angel of the Co-O-P bond $\left(121.38^{\circ}-157.59^{\circ}\right)$ in $\mathrm{Co}\left(\mathrm{PO}_{3}\right)_{2}$ is also longer than $\mathrm{O}-\mathrm{Co}-\mathrm{O}$ bond $\left(109.47^{\circ}\right)$ in $\mathrm{CoO}$, resulting in a distorted coordination geometry. This result was consistent with previous reports and indicates that their structure contributes to stabilization of the reactive intermediate [38]. Based on the above advanced spectroscopic techniques and DFT calculations, there are three possible explanations for the high catalysis characteristics our synthesized cost-effective $\mathrm{Co}\left(\mathrm{PO}_{3}\right)_{2} / \mathrm{NC}$ : (1) Compared with $\mathrm{CoO}$, the introduction of $\mathrm{P}$ tunes the length of Co-O bond and the angel of $\mathrm{O}-\mathrm{Co}-\mathrm{O}$ bond, which provide positive contributions for structural stability, (2) the excited synergistic effect of the $\mathrm{N}$-doped carbon layer and $\mathrm{Co}\left(\mathrm{PO}_{3}\right)_{2} \mathrm{NPs}$ are beneficial to accelerate $\mathrm{ORR}$, (3) $\mathrm{Co}\left(\mathrm{PO}_{3}\right)_{2}$ groups as the main active site may be attributed to its excellent proton transfer properties, thus facilitating the ORR process. 


\section{[Figure 5]}

\section{Conclusions}

In summary, the $\mathrm{Co}\left(\mathrm{PO}_{3}\right)_{2}$ decorated with $\mathrm{N}$-doped graphitic carbon have been designed to comprehend the relationship between the nanostructure and the electrocatalytic activity toward ORR. We offer a simple one step method to develop a new alternative precursor for efficiently catalyst for ORR. The proposed $\mathrm{Co}\left(\mathrm{PO}_{3}\right)_{2} / \mathrm{NC}$ presents a better ORR properties than $\mathrm{Co}\left(\mathrm{PO}_{3}\right)_{2}$ in alkaline electrolyte which can be ascribed to the excited synergistic effect between $\mathrm{N}$-doped carbon layer and $\mathrm{Co}\left(\mathrm{PO}_{3}\right)_{2} \mathrm{NPs}$ which are beneficial to accelerate ORR. Our study shed light up an effective route to rational design and scalable fabrication of $\mathrm{Co}\left(\mathrm{PO}_{3}\right)_{2}$ with cost-effective, high-active, and long-term stability. It is currently working to modify specific metal center ions with different ligands to regulate their structural properties and further enhance the catalytic activity.

\section{AUTHOR INFORMATION}

\section{Corresponding Authors}

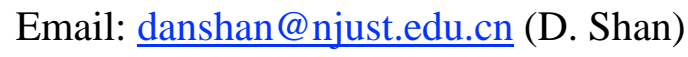

zhangslvip@njust.edu.cn (S.L. Zhang)

wangwenju1982@gmail.com (W.J. Wang) 
Fax: 0086-25-84303107

\section{Notes}

The authors declare no competing financial interest

\section{Acknowledgements}

This research was supported by National Natural Science Foundation of China (Grant No.21675086), the Fundamental Research Funds for the Central Universities (No.30918012202), and a project founded by the priority academic program development of Jiangsu Higher Education Institutions (PAPD). The authors wish also to acknowledge the support from the Sino-French international research network "New nanostructured materials and biomaterials for renewable electrical energy sources" for providing facilities.

\section{References:}

[1] H.W. Kim, V.J. Bukas, H. Park, S. Park, K.M. Diederichsen, J. Lim, Y.H. Cho, J.

Kim, W. Kim, T.H. Han, J. Voss, A.C. Luntz, B.D. McCloskey, Mechanisms of Two-Electron and Four-Electron Electrochemical Oxygen Reduction Reactions at Nitrogen-Doped Reduced Graphene Oxide, ACS Catal. 10 (2019) 852-863.

[2] M. Qiao, Y. Wang, Q. Wang, G. Hu, X. Mamat, S. Zhang, S. Wang, Hierarchically Ordered Porous Carbon with Atomically Dispersed $\mathrm{FeN}_{4}$ for Ultraefficient Oxygen Reduction Reaction in Proton-Exchange Membrane Fuel Cells, Angew. Chem. Int. Ed. Engl. 59 (2020) 2688-2694. 
[3] T. Sun, P. Zhang, W. Chen, K. Wang, X. Fu, T. Zheng, J. Jiang, Single iron atoms coordinated to $\mathrm{g}-\mathrm{C}_{3} \mathrm{~N}_{4}$ on hierarchical porous $\mathrm{N}$-doped carbon polyhedra as a high-performance electrocatalyst for the oxygen reduction reaction, Chem. Commun. (Cambridge, U. K.) 56 (2020) 798-801.

[4] J. Yang, F. Xiang, H. Guo, L. Wang, X. Niu, Honeycomb-like porous carbon with $\mathrm{N}$ and $\mathrm{S}$ dual-doping as metal-free catalyst for the oxygen reduction reaction, Carbon 156 (2020) 514-522.

[5] L. He, J. Liu, B. Hu, Y. Liu, B. Cui, D. Peng, Z. Zhang, S. Wu, B. Liu, Cobalt oxide doped with titanium dioxide and embedded with carbon nanotubes and graphene-like nanosheets for efficient trifunctional electrocatalyst of hydrogen evolution, oxygen reduction, and oxygen evolution reaction, J. Power Sources 414 (2019) 333-344.

[6] Z.S. Cai, Y. Shi, S. S. Bao, Y. Shen, X. H. Xia, L. M. Zheng, Bioinspired Engineering of Cobalt-Phosphonate Nanosheets for Robust Hydrogen Evolution Reaction, ACS Catal. 8 (2018) 3895-3902.

[7] Y. Chang, N.E. Shi, S. Zhao, D. Xu, C. Liu, Y.J. Tang, Z. Dai, Y.Q. Lan, M. Han, J. Bao, Coralloid $\mathrm{Co}_{2} \mathrm{P}_{2} \mathrm{O}_{7}$ Nanocrystals Encapsulated by Thin Carbon Shells for Enhanced Electrochemical Water Oxidation, ACS Appl. Mater. Inter. 8 (2016) 22534-22544.

[8] L. Vilciauskas, M.E. Tuckerman, G. Bester, S.J. Paddison, K.D. Kreuer, The mechanism of proton conduction in phosphoric acid, Nat. Chem. 4 (2012) 461-466.

[9] V.V. Mulloyarova, I.S. Giba, G.S. Denisov, A.S. Ostras, P.M. Tolstoy, 
Conformational Mobility and Proton Transfer in Hydrogen-Bonded Dimers and Trimers of Phosphinic and Phosphoric Acids, J. Phys. Chem. A 123 (2019) 6761-6771.

[10] C. Z. Yuan, Y. F. Jiang, Z. Wang, X. Xie, Z. K. Yang, A.B. Yousaf, A.W. Xu, Cobalt phosphate nanoparticles decorated with nitrogen-doped carbon layers as highly active and stable electrocatalysts for the oxygen evolution reaction, J Mater. Chem. A 4 (2016) 8155-8160.

[11] H. Zhao, C.-C. Weng, J.-T. Ren, L. Ge, Y.-P. Liu, Z.-Y. Yuan, Phosphonate-derived nitrogen-doped cobalt phosphate/carbon nanotube hybrids as highly active oxygen reduction reaction electrocatalysts, Chin. J. Catal. 41 (2020) 259-267.

[12] B. Liu, H.Q. Peng, C.N. Ho, H. Xue, S. Wu, T.W. Ng, C.S. Lee, W. Zhang, Mesoporous Nanosheet Networked Hybrids of Cobalt Oxide and Cobalt Phosphate for Efficient Electrochemical and Photoelectrochemical Oxygen Evolution, Small 13 (2017).

[13] H.S. Ahn, T.D. Tilley, Electrocatalytic Water Oxidation at Neutral $\mathrm{pH}$ by a Nanostructured $\mathrm{Co}\left(\mathrm{PO}_{3}\right)_{2}$ Anode, Adv. Funct. Mater. 23 (2013) 227-233.

[14] R. Pothiraja, M. Sathiyendiran, R.J. Butcher, R. Murugavel, Non-interpenetrating transition metal diorganophosphate 2-dimensional rectangular grids from their 1-dimensional wires: Structural, transformations under mild conditions, Inorg. Chem. 44 (2005) 6314-6323.

[15] Y. Zhan, S. Yang, M. Lu, Z. Liu, J.Y. Lee, The development of cobalt phosphate 
for bifunctional oxygen electrocatalysis in alkaline solution, Electrochim. Acta 227 (2017) 310-316.

[16] R. Gond, D.K. Singh, M. Eswaramoorthy, P. Barpanda, Sodium Cobalt Metaphosphate as an Efficient Oxygen Evolution Reaction Catalyst in Alkaline Solution, Angew. Chem. Int. Ed. Engl. 58 (2019) 8330-8335.

[17] T. Zhou, Y. Du, S. Yin, X. Tian, H. Yang, X. Wang, B. Liu, H. Zheng, S. Qiao, R. $\mathrm{Xu}$, Nitrogen-doped cobalt phosphate@nanocarbon hybrids for efficient electrocatalytic oxygen reduction, Energy Environ. Sci. 9 (2016) 2563-2570.

[18] H.S. Ahn, T.D. Tilley, Electrocatalytic Water Oxidation at Neutral pH by a Nanostructured $\mathrm{Co}\left(\mathrm{PO}_{3}\right)_{2}$ Anode, Adv. Funct. Mater., 23 (2013) 227-233.

[19] R. Gond, D.K. Singh, M. Eswaramoorthy, P. Barpanda, Sodium Cobalt Metaphosphate as an Efficient Oxygen Evolution Reaction Catalyst in Alkaline Solution, Angew. Chem. Int. Ed. Engl. 58 (2019) 8330-8335.

[20] R. Gond, R.P. Rao, V. Pralong, O.I. Lebedev, S. Adams, P. Barpanda, Cubic Sodium Cobalt Metaphosphate $\left[\mathrm{NaCo}\left(\mathrm{PO}_{3}\right)_{3}\right]$ as a Cathode Material for Sodium Ion Batteries, Inorg. Chem. 57 (2018) 6324-6332.

[21] J. Huang, Y. Sun, Y. Zhang, G. Zou, C. Yan, S. Cong, T. Lei, X. Dai, J. Guo, R. Lu, Y. Li, J. Xiong, A New Member of Electrocatalysts Based on Nickel Metaphosphate Nanocrystals for Efficient Water Oxidation, Adv. Mater. 30 (2018) 1705045.

[22] T. Hoffmann, P. Friedel, C. Harnisch, L. Häußler, D. Pospiech, Investigation of thermal decomposition of phosphonic acids, J. Anal. Appl. Pyrolysis 96 (2012) 43-53. 
[23] G. Kresse, J. Hafner, Ab initio molecular dynamics for liquid metals. Phys. Rev. B 47 (1993) 558.

[24] G. Kresse, J. Hafner, Ab initio molecular-dynamics simulation of the liquid-metal-amorphous-semiconductor transition in germanium. Phys. Rev. B 49 (1994) 14251.

[25] P.E. Blöchl, Projector augmented-wave method. Phys. Rev. B 50 (1994) 17953.

[26] G. Kresse, D. Joubert. From ultrasoft pseudopotentials to the projector augmented-wave method. Phys. Rev. B 59 (1999) 1758.

[27] C. Chen, C.H. Shen, G.J. Kong, S.J. Gao, High temperature proton exchange membranes prepared from epoxycyclohexylethyltrimethoxysilane and amino trimethylene phosphonic acid as anhydrous proton conductors, Mater. Chem. Phys. 140 (2013) 24-30.

[28] A. Dołęga, A. Pladzyk, K. Baranowska, J. Jezierska, Biomimetic zinc(ii) and cobalt(ii) complexes with tri-tert-butoxysilanethiolate and imidazole ligands-structural and spectroscopic studies. Inorg. Chim. Acta 362 (2009) 5085-5096.

[29] S. Rajendran, B.V. Apparao, N. Palaniswamy, Synergistic, antagonistic and biocidal effects of amino (trimethylene phosphonic acid), polyacrylamide and $\mathrm{zn}^{2+}$ on the inhibition of corrosion of mild steel in neutral aqueous environment. Anti-Corros. Methods Mater. 44 (1997) 308-313.

[30] H. Jiang, Y. Wang, J. Hao, Y. Liu, W. Li, J. Li, N and P co-functionalized three-dimensional porous carbon networks as efficient metal-free electrocatalysts for oxygen reduction reaction, Carbon 122 (2017) 64-73. 
[31] C. Zhang, J. Liu, Y. Ye, Q. Chen, C. Liang, Encapsulation of Co-based nanoparticle in $\mathrm{N}$-doped graphitic carbon for efficient oxygen reduction reaction, Carbon 156 (2020) 31-37.

[32] W.J. Niu, R. H. Zhu, H. Yan, H. B. Zeng, S. Cosnier, X.J. Zhang, D. Shan, One-pot synthesis of nitrogen-rich carbon dots decorated graphene oxide as metal-free electrocatalyst for oxygen reduction reaction, Carbon 109 (2016) 402-410.

[33] M. Chen, L.L. Shao, Y.X. Guo, X.Q. Cao, Nitrogen and phosphorus co-doped carbon nanosheets as efficient counter electrodes of dye-sensitized solar cells, Chem. Eng. J. 304 (2016) 303-312.

[34] A. Zehtab Yazdi, E.P.L. Roberts, U. Sundararaj, Nitrogen/sulfur co-doped helical graphene nanoribbons for efficient oxygen reduction in alkaline and acidic electrolytes, Carbon 100 (2016) 99-108.

[35] S. Cai, Z. Meng, H. Tang, Y. Wang, P. Tsiakaras, 3D Co-N-doped hollow carbon spheres as excellent bifunctional electrocatalysts for oxygen reduction reaction and oxygen evolution reaction, Appl. Catal. B-Environ. 217 (2017) 477-484.

[36] R. Li, Z. Wei, X. Gou, Nitrogen and Phosphorus Dual-Doped Graphene/Carbon Nanosheets as Bifunctional Electrocatalysts for Oxygen Reduction and Evolution, ACS Catal. 5 (2015) 4133-4142.

[37] T.H. Zhou, D.P. Wang, S.C.K. Goh, J.D. Hong, J.Y. Han, J.G. Mao, R. Xu, Bio-inspired organic cobalt (II) phosphonates toward water oxidation. Energy Environ. Sci. 8 (2015) 526-534.

[38] T.F. Li, H.J. Deng, J.J. Liu, C. Jin, Y. Song, F. Wang, First-row transition metals 
and nitrogen co-doped carbon nanotubes: The exact origin of the enhanced activity for oxygen reduction reaction, Carbon 143 (2019) 859-868. 


\section{Figure Captions}

Figure 1. (A) UV-vis absorption spectra of ATMP, Co(II) and precursor in $\mathrm{H}_{2} \mathrm{O} / \mathrm{CH}_{3} \mathrm{OH}\left(V_{\mathrm{H}_{2} \mathrm{O}}: V_{\mathrm{CH}_{3} \mathrm{OH}}=1: 10\right)$. (B) FI-IR spectra of ATMP and the precursor. (C) Solid UV-vis absorption spectra of the precursor. (D) TG and DTA curves of the precursor in $\mathrm{N}_{2}$ atmosphere with a heating rate of $10{ }^{\circ} \mathrm{C} \min ^{-1}$.

Figure 2. (A) XRD patterns of $\mathrm{Co}\left(\mathrm{PO}_{3}\right)_{2} / \mathrm{NC}$ and $\mathrm{Co}\left(\mathrm{PO}_{3}\right)_{2}$. (B) Raman spectrum of $\mathrm{Co}\left(\mathrm{PO}_{3}\right)_{2} / \mathrm{NC}$. (C) EDS mapping of $\mathrm{Co}\left(\mathrm{PO}_{3}\right)_{2} / \mathrm{NC}$. (D, E) SEM, (F) TEM, and (G) HRTEM images of $\mathrm{Co}\left(\mathrm{PO}_{3}\right)_{2} / \mathrm{NC}$.

Figure 3. (A) Full XPS spectra and high resolution XPS spectra of (B) $N$ 1s of $\mathrm{Co}\left(\mathrm{PO}_{3}\right)_{2} / \mathrm{NC}$ catalyst, (C) $\mathrm{P} 2 \mathrm{p}$ and (D) $\mathrm{Co} 2 \mathrm{p}$ of $\mathrm{Co}\left(\mathrm{PO}_{3}\right)_{2} / \mathrm{NC}$ and $\mathrm{Co}\left(\mathrm{PO}_{3}\right)_{2}$ catalysts.

Figure 4. (A) $\mathrm{CV}$ curve of $\mathrm{Co}\left(\mathrm{PO}_{3}\right)_{2} / \mathrm{NC}$ in $\mathrm{N}_{2}$-saturated versus $\mathrm{O}_{2}$-saturated in $0.1 \mathrm{M}$ $\mathrm{KOH}$ electrolyte at a scan rate of $10 \mathrm{mV} \mathrm{s}^{-1}$. (B) LSV curves of $\mathrm{NC}, \mathrm{CoO}, \mathrm{Co}\left(\mathrm{PO}_{3}\right)_{2}$, $\mathrm{Co}\left(\mathrm{PO}_{3}\right)_{2} / \mathrm{NC}$ and commercial $20 \% \mathrm{Pt} / \mathrm{C}$ in $0.1 \mathrm{M} \mathrm{KOH}$ electrolyte with a rotation speed of $1600 \mathrm{rpm}$. (C) The i-t chronoamperometric curves and (D) Methanol crossover tolerance test of $\mathrm{Co}\left(\mathrm{PO}_{3}\right)_{2} / \mathrm{NC}$ and commercial $20 \% \mathrm{Pt} / \mathrm{C}$ catalysts at $0.4 \mathrm{~V}$ (vs. RHE) in $\mathrm{O}_{2}$-saturated $0.1 \mathrm{M} \mathrm{KOH}$ electrolyte.

Figure 5. (A) The band structure of $\mathrm{Co}\left(\mathrm{PO}_{3}\right)_{2}$ crystal, (B) The projected density of states for $\mathrm{Co}\left(\mathrm{PO}_{3}\right)_{2}$ crystal, (C) The charge densities corresponding to valence band maximum (VBM) and conduction band minimum $(\mathrm{CBM})$ for $\mathrm{Co}\left(\mathrm{PO}_{3}\right)_{2}$ crystal. The isosurface value is set to $0.002 \mathrm{e} \mathrm{Bohr}^{3}$, (D) Schematic diagram of the computational structural model of $\mathrm{Co}\left(\mathrm{PO}_{3}\right)_{2} / \mathrm{NC}$. (E) Side view of the binding configurations of $* \mathrm{OH}$, 
$* \mathrm{O}$, and $* \mathrm{OOH}$ on the $\mathrm{Co}\left(\mathrm{PO}_{3}\right)_{2} / \mathrm{NC}$. (F)The free energy profile for the ORR pathway $(\mathrm{U}=0)$ over $\mathrm{Co}\left(\mathrm{PO}_{3}\right)_{2} / \mathrm{NC}, \mathrm{Co}\left(\mathrm{PO}_{3}\right)_{2}, \mathrm{Co}_{\text {site }}-\mathrm{N}_{\text {site }}, \mathrm{NC}$ and $\mathrm{CoO}$.

Scheme 1. Schematic illustration of the fabrication process of the $\mathrm{Co}\left(\mathrm{PO}_{3}\right)_{2} / \mathrm{NC}$. 

Figure 1

(A)

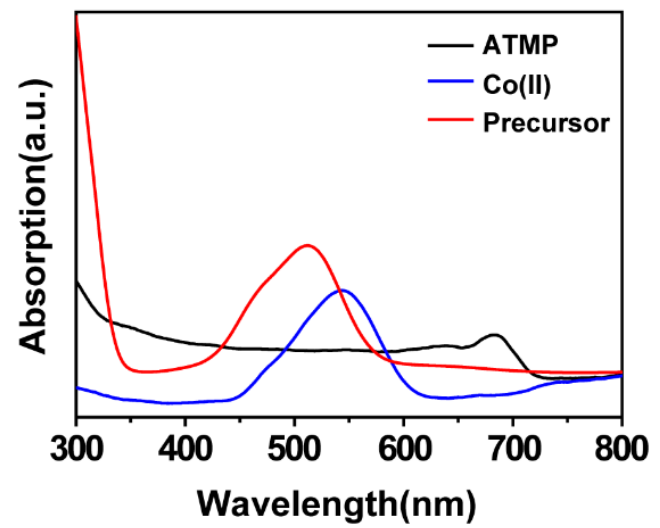

(C)

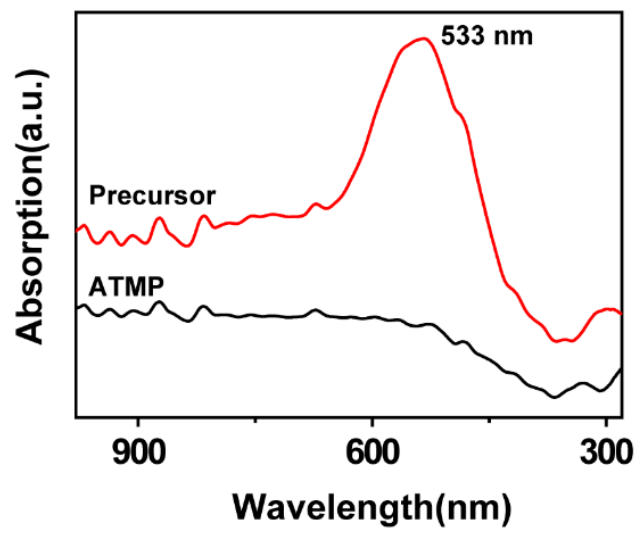

(B)

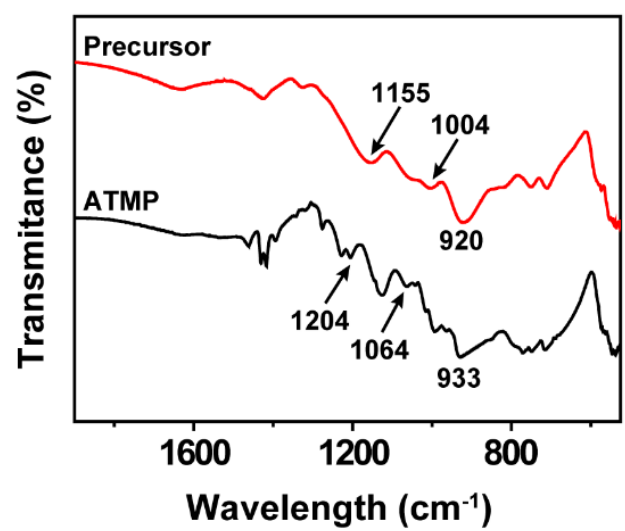

(D)

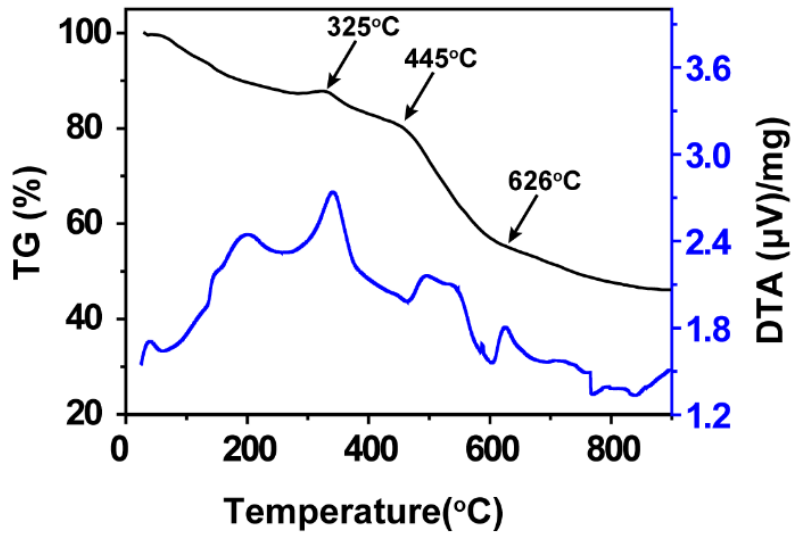


Figure 2

(A)
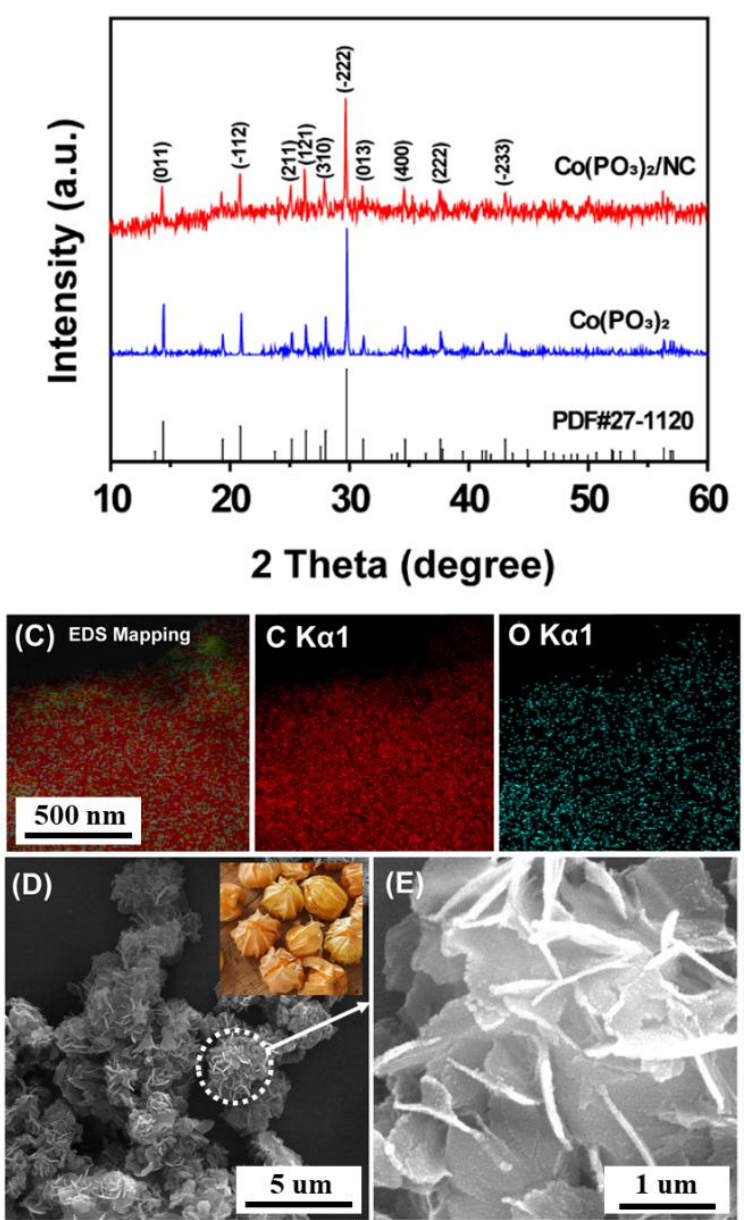

(B)
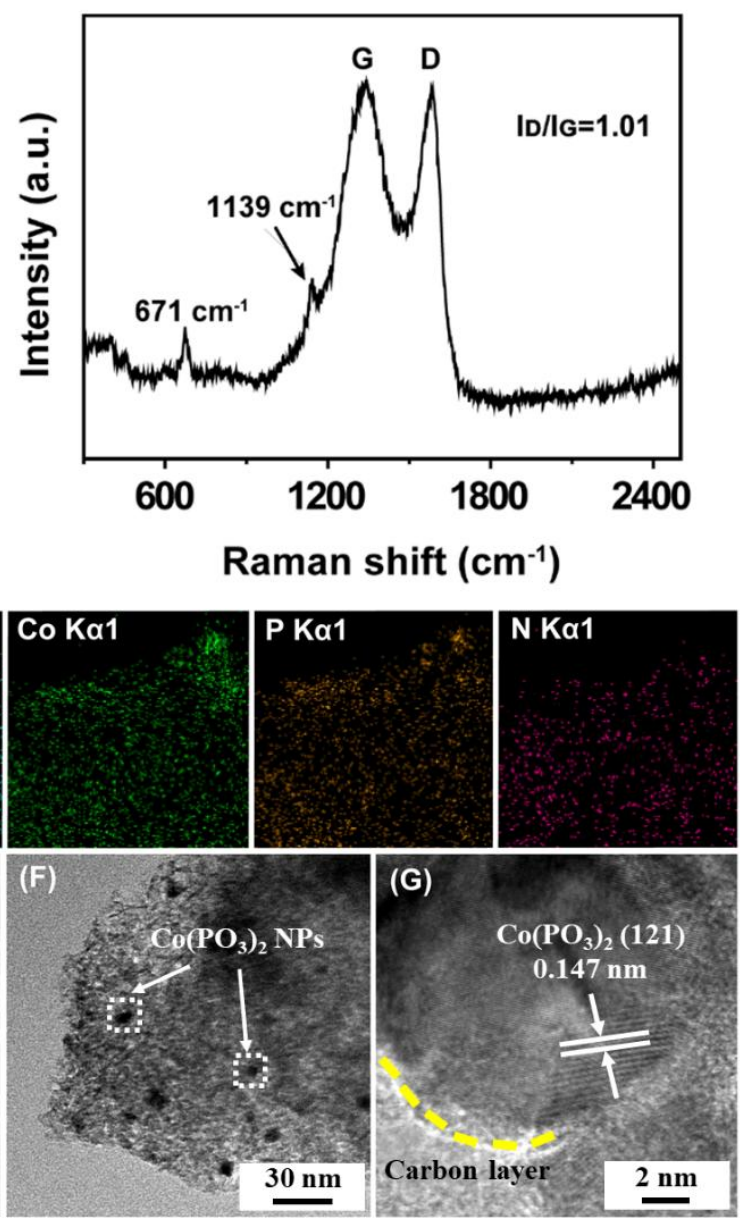

(G)

$0.147 \mathrm{~nm}$

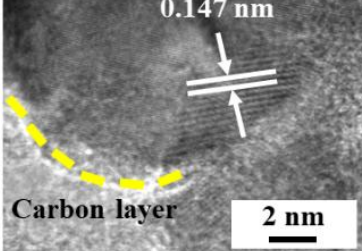


Figure 3

(A)

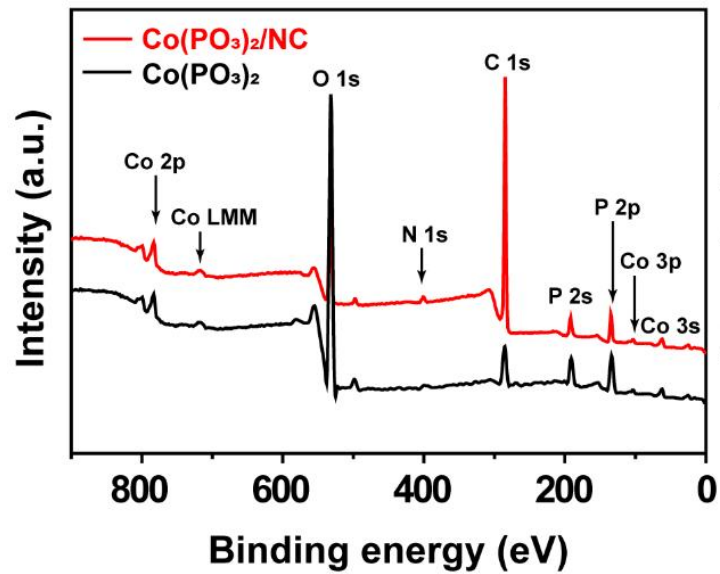

(C)

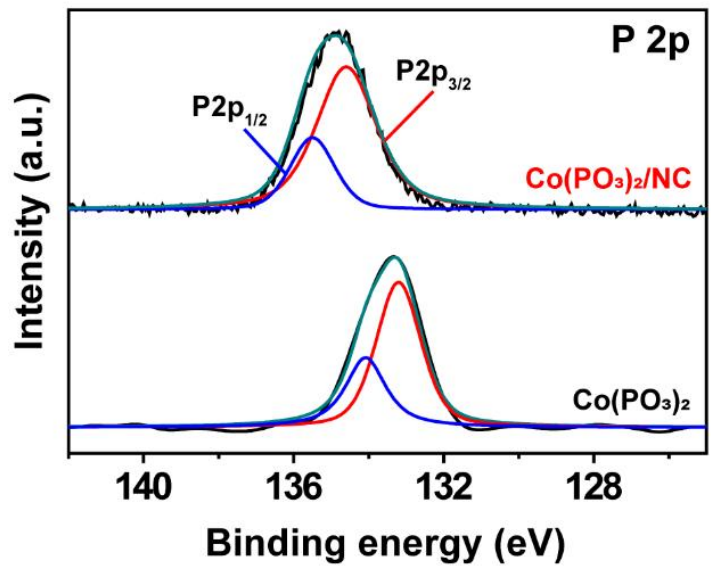

(B)

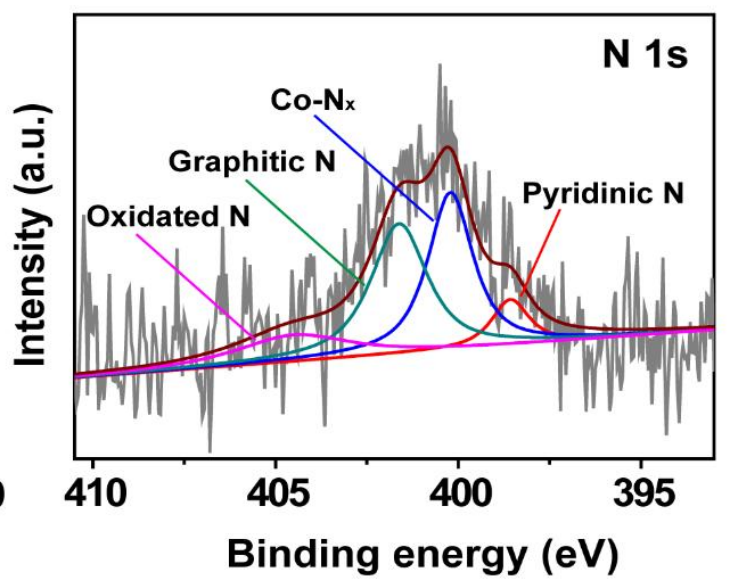

(D)

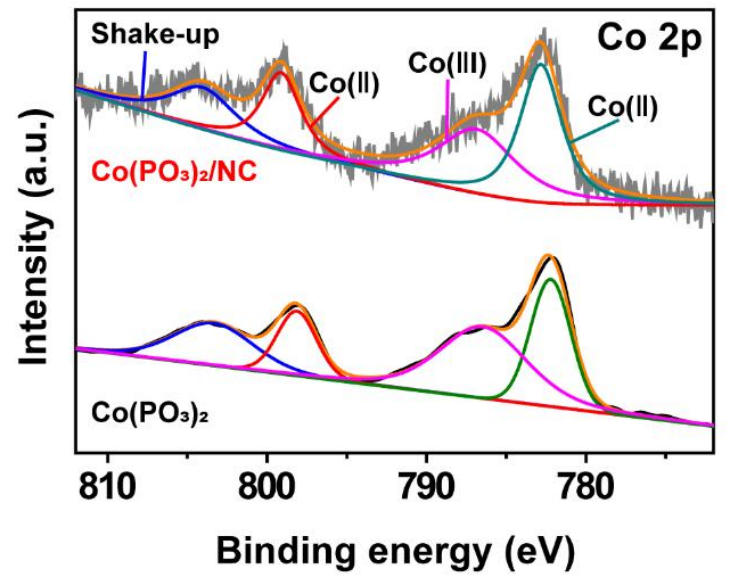


Figure 4

(A)

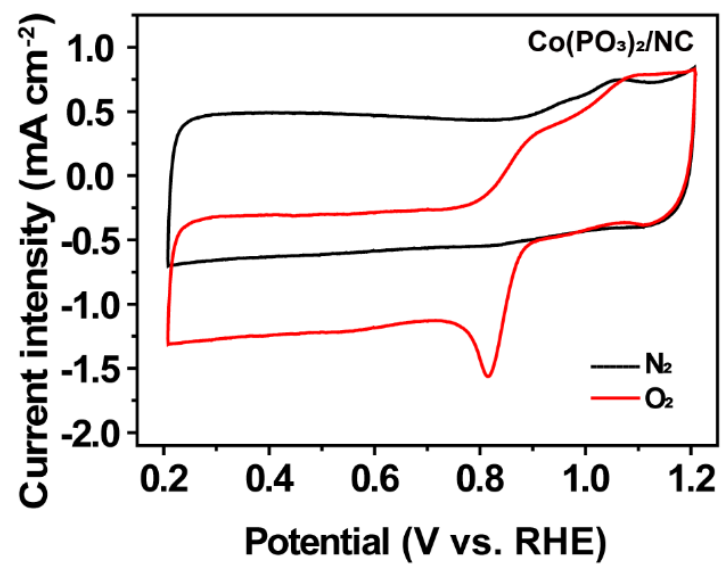

(C)

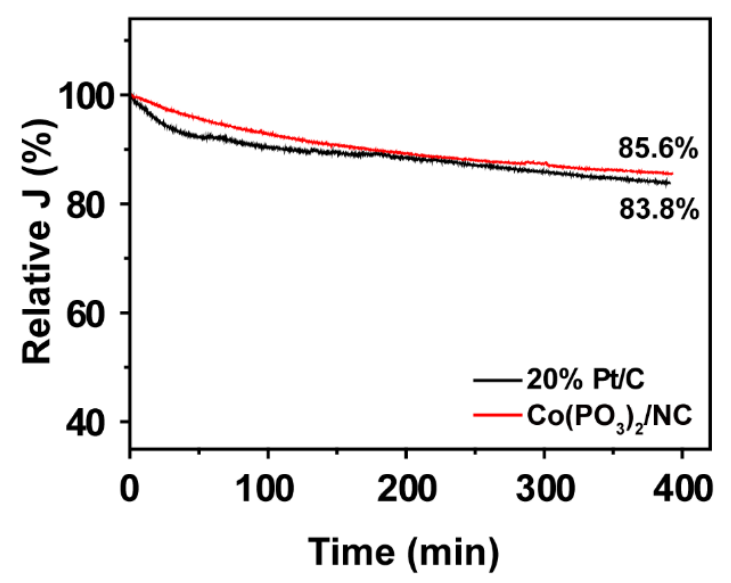

(B)

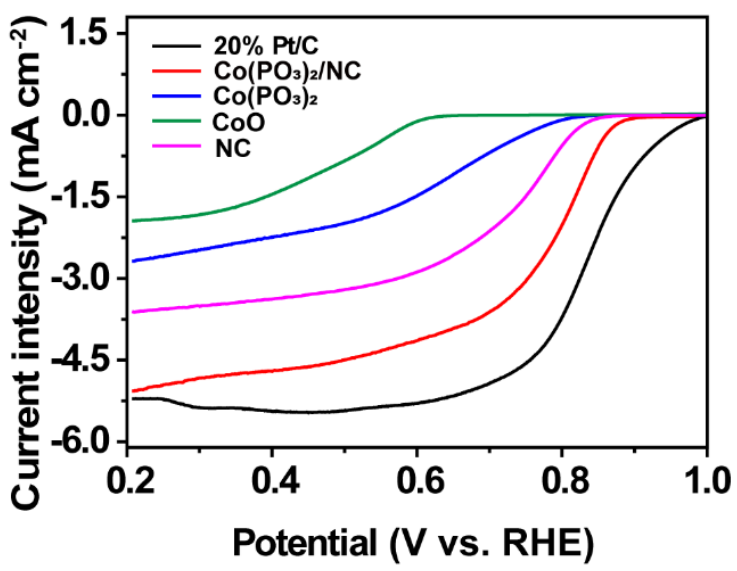

(D)

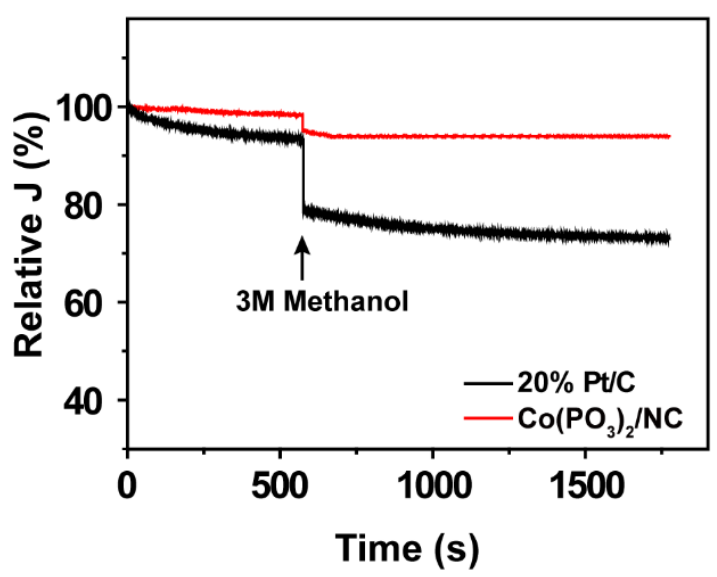


Figure 5

(A) $\quad \mathrm{Co}\left(\mathrm{PO}_{3}\right)_{2}$

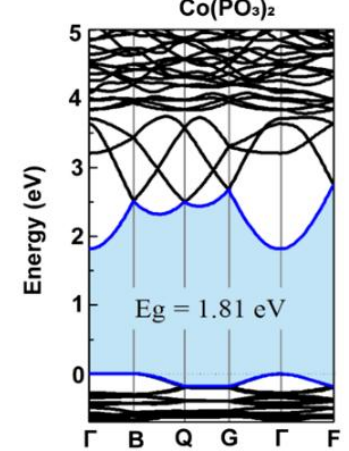

(E)

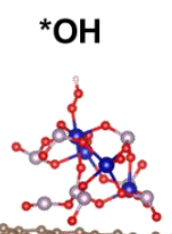

(B)

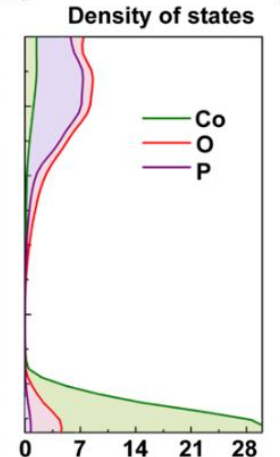

(C)

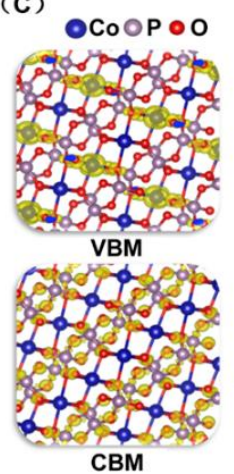

(D)

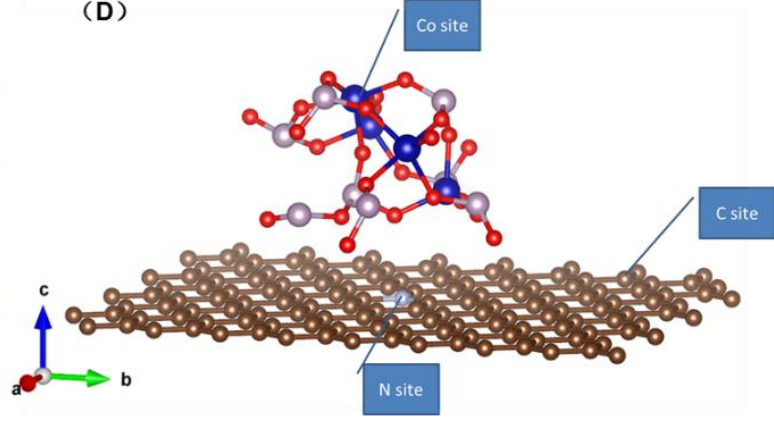

(F)

Reaction Coordinates

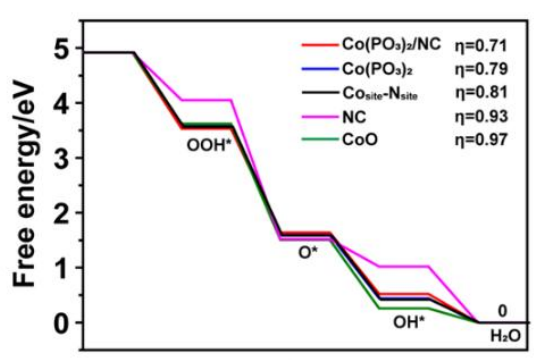




\section{Scheme 1}

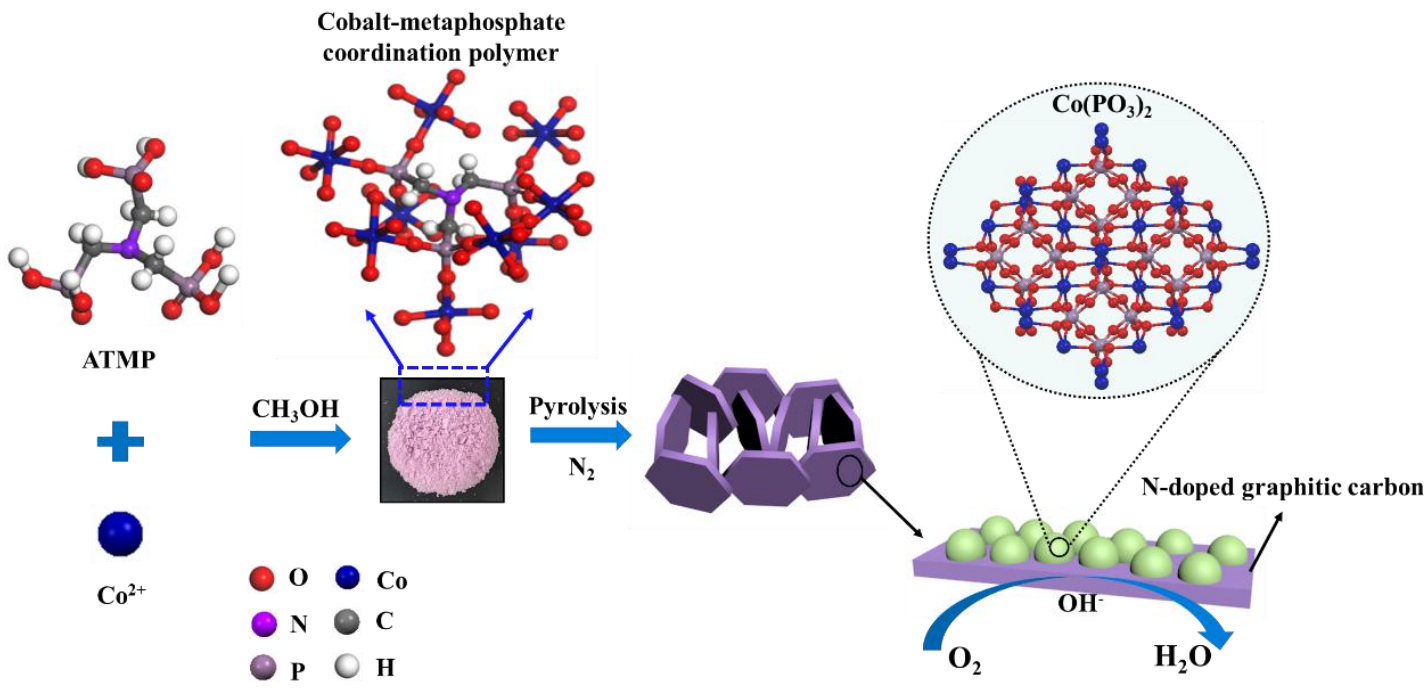

